\title{
OPTICAL PROPERTIES OF EUROPIUM COMPOUNDS WITH L- AND DL- $\alpha$-ALANINE-HYDROXAMIC ACIDS
}

\author{
J. Legendziewicz, P. GawryszewsKa
}

Faculty of Chemistry, University of Wrocław

14 F. Joliot-Curie, 50-383 Wrocław, Poland

\section{E. Galdecka}

Institute for Low Temperature and Structure Research

Polish Academy of Sciences

Okólna 2, 50-950 Wroclaw, Poland

AND Z. GaLdecki

Institute of General and Ecological Chemistry, Technical University of Łódź Żwirki 36, 90-924 Łódź, Poland

Two of europium complexes with L- and DL- $\alpha$-alanine-hydroxamic acids were synthesized. To our knowledge they are the first examples of X-ray and spectral data of lanthanide single crystals with hydroxamic acid derivatives. Both compounds consist of dimers in their structures, formed by two OH bridging groups of amino-liydroxamic acid molecules. Besides, two metal ions are chelated by $\mathrm{CO}$ and $\mathrm{OHI}$ groups, forming five-membered rings. In the complex with L-ligand, different than in the DL-one, two additional perchloric acid molecules are included in crystal cavities and form hydrogen bondings witl nitrogen and oxygen atoms of the ligand. Absorption, emission and excitation spectra were measured and analyzed at room and low temperatures. Structural effect of ligand chirality was found and its spectroscopic consequences are reported. The effect of the dimeric structure on spectroscopic properties is discussed.

PACS numbers: 78.20.Wc, 78.55.Hx, 61.66.Fn, 78.20.Dj

\section{Introduction}

In recent decade a great interest on metal ions interactions with hydroxamic acid and its amino derivatives was observed. The main reason of that is their role in biological processes. Compounds containing hydroxamic acid are ubiquitous and intimately associated with phenomena of iron transport. 
It is also known that hydroxamic acid moiety is a constituent of growth factors, tumor inlibitors, cell-division factors, etc. [1-7]. Ilydroxamic acids are also specific inhibitors of urease activity [8] and aminopeptidases. Inhibition of these enzymes appears to involve chelation of metal ions at hydroxamic acid active sites. Amino-hydroxamic acids have very unique donor chelating atoms: two nitrogen and two oxygen; besides, they liave more complicated acid-base properties.

The most of reports deal with copper and iron complexes for their importance [9-13], a few treat with lanthanide ions [14-16].

Since lanthanides are usually used as spectroscopic probes in the studies of biomolecules, especially of calcium binding proteins, it seemed important to investigate interactions of lanthanide ions with the above systems.

\section{Experimental details}

Europium compound with DL- (I) and L- $\alpha$-alanine-hydroxamic acid(II) (further denoted as $\Lambda$ II $A$ ) was obtained from aqueous solution of lanthanide perchlorate $\left(C \approx 10^{-2} \mathrm{M}\right)$. The molecular ratio $1: 1.5$ of Eu:A IIA was kept. Concentration of metal in crystals was determined complexometrically and by inductively coupled plasma atomic emission spectrometry (ICP AES) method, other elements were determined by elemental analysis.

The crystal density was measured by flotation method in a mixture of bromoform and ethylene bromide. The absorption spectra in $293-82 \mathrm{~K}$ range were recorded by a Cary-Varian 5 spectrophotometer equipped with an Oxford helium flow cryostat. The excitation and emission spectra were done at 77 and $293 \mathrm{~K}$ using a SLM Aminco SPF 500 spectrofluorometer. Raman spectra were measured using a DFS 24 double monochromator $\left(f=0.82 \mathrm{~m}\right.$, accuracy $\left.\pm 1 \mathrm{~cm}^{-1}\right)$, equipped with photon counting system (cooled GaAs photomultiplier). Excitation source was an argon laser $(l=488,514.3 \mathrm{~nm})$.

\section{Results and discussion}

Figure 1 shows the view of structure of europium compound with DL- $\alpha$-alanine-hydroxamic acid. The $\mathrm{NII}_{2}-$ groups and hydroxamic acid groups are in a position with respect to each other and possess the ability to form three types of five-membered chelating rings (two $\mathrm{N}$ atoms, two $\mathrm{O}$ atoms, or both two $\mathrm{N}$ and two $\mathrm{O}$ atoms). In creation of the chelating ring with a lanthanide the second type of coordination is involved. Besides, OII group plays an additional bridging role, forming binuclear systems. Centrosymmetric dimers exist in the complexes with DL-ligand form, whereas in the compound with L-lhanded ligand the dimers could possess $\mathrm{C} 2$ axes or, as noncentrosymmetric unit, two nonequivalent lanthanide positions can be considered. Details of crystal structure refinement and structural data are the subject of separate paper [17]. On the other hand, in the second type of compound two molecules of $\mathrm{IIClO}_{4}$ exist in the structure, forming dynamic hydrogen bonding with $\mathrm{C}=\mathrm{O}$ and $\mathrm{N}$ sites of the ligand.

Formation of OII bridge in lantlianide systems is very rarely reported yet. In crystal structure data for $d$-metal compounds, the first two types of coordination were found [18] and neither III type nor bridging by OII group were reported. According to available $\mathrm{X}$-ray data for $\mathrm{Cu}^{2+}$ with $\alpha$-alanine-hydroxamic 


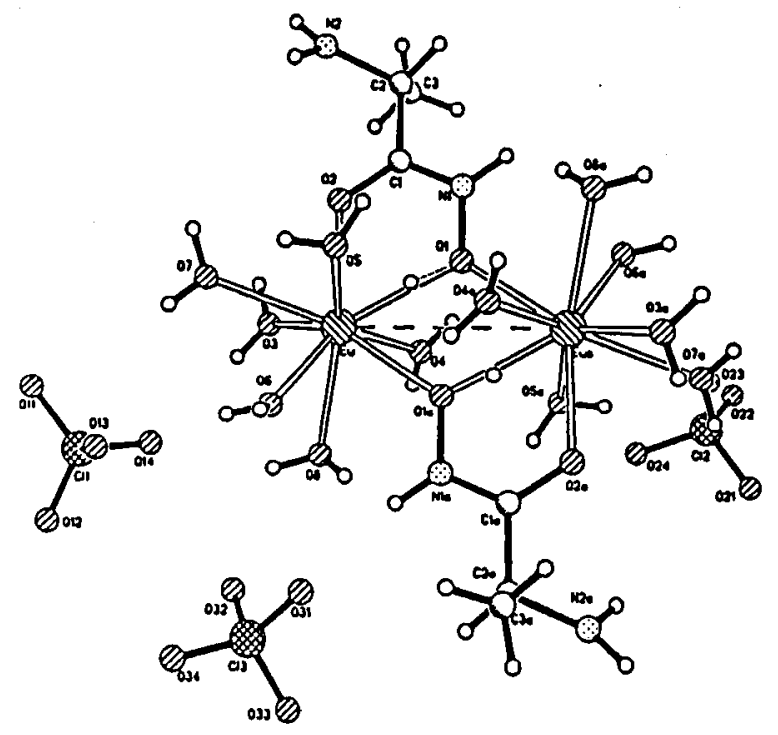

Fig. 1. Crystal structure of $\left.\left[\mathrm{Eu}(\mathrm{DL}-\alpha-\mathrm{A}]_{a} \mathrm{ha}\right)\left(\mathrm{H}_{2} \mathrm{O}\right)_{6}\right]_{2}\left(\mathrm{ClO}_{4}\right)_{6}$ : space group $P 2_{1} / n, a=$ 10.345 $\AA, b=11.312 \AA, c=16.957 \AA, \alpha=90.00^{\circ}, \beta=95.39^{\circ}, \gamma=90.00^{\circ}$, Eu-Eua $=$ $4.114 \AA ;\left[\mathrm{Eu}(\mathrm{L}-\alpha \text {-AlahlaII })\left(\mathrm{H}_{2} \mathrm{O}\right)_{6}\right]_{2}\left(\mathrm{ClO}_{4}\right)_{8}$ : space group $P 1, a=8.623 \AA, b=10.855 \AA$, $c=15.898 \AA, \alpha=105.86^{\circ}, \beta=90.05^{\circ}, \gamma=113.39^{\circ}$, Eu1-Eu2 $=4.079 \AA$.

acid, polynuclear systems exist most probably in solution, too [19]. For the reason of very soft acid-base equilibrium, depending on the pII of solution, different groups could be deprotonated. The title crystal was grown up at $\mathrm{pII} \approx 4$. However, in the compounds presented here the NOII groups remain protonated, which was fine detected in X-ray data [17].

Let us now turn our attention to the optical properties of the systems under investigation. It was shown from the X-ray analysis for compound I that centrosymmetric dimer follows one symmetry centre of metal ion. It meets good confirmation in ${ }^{7} F_{0} \rightarrow{ }^{5} D_{0}$ transition both in luminescence and excitation spectra (one component; Figs. 2a,b and 3a,b). Comparison of the emission and excitation spectra for compounds I and II indicates the decrease in symmetry, which is well manifested both in the splitting pattern of bands, as well as in relative intensities of ${ }^{5} D_{0} \rightarrow{ }^{7} F_{0} ;{ }^{7} F_{1}$ and ${ }^{7} F_{2}$, and ${ }^{7} F_{0} \rightarrow{ }^{5} D_{J}$ transitions.

In the emission spectra the complex structure of bands for compound II at $77 \mathrm{~K}$ indicates a decrease in symmetry of dimer system and seems to confirm rather the noncentrosymmetric dimer with two nonequivalent metal sites. The $5 \mathrm{~K}$ luminescence and excitation spectra could solve this problem.

Ilowever, lowering of temperature down to $82 \mathrm{~K}$ (compound I) leads to the significant shift of the optical lines, as it usually happens in dimer systems [20], but this could also indicate a soft change of conformation of the studied system (Fig. 4). This phenomenon, as well as luminescence quenching, will be the subject of our further studies. 

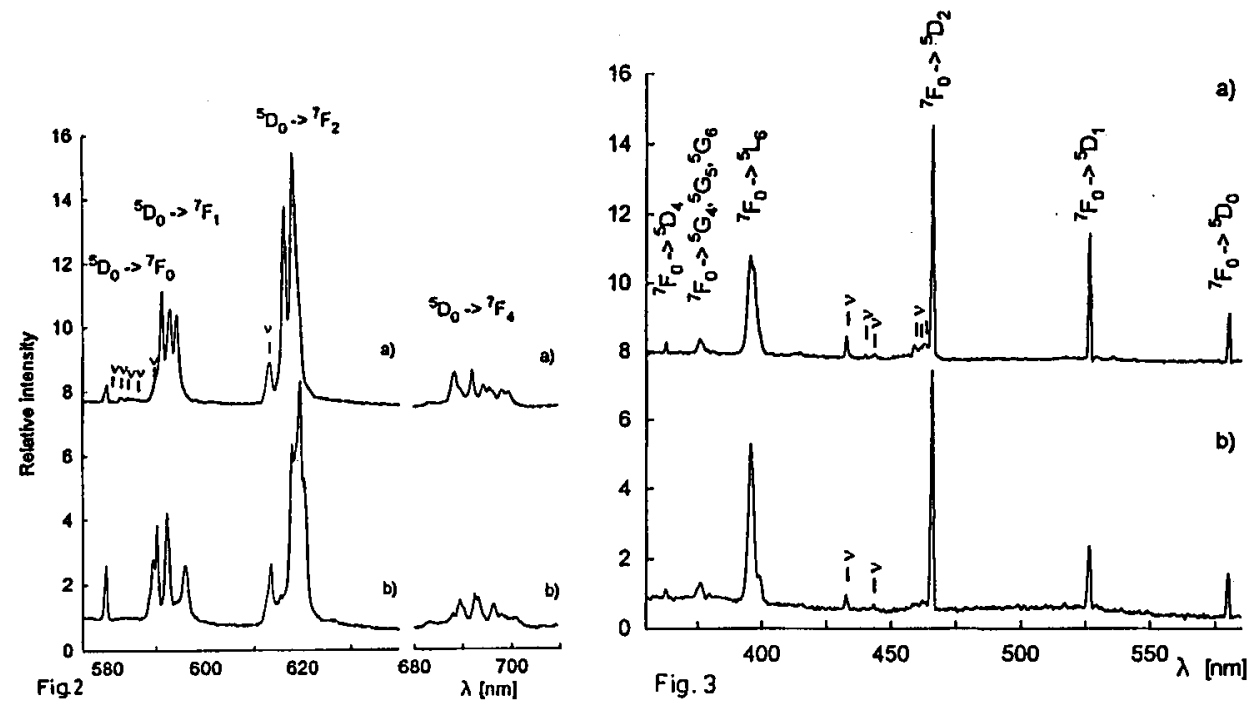

Fig. 2. Fluorescence spectra of (a) $\left[\mathrm{Eu}(\mathrm{DL}-\alpha-\mathrm{Alaha})\left(\mathrm{H}_{2} \mathrm{O}\right)_{6}\right]_{2}\left(\mathrm{ClO}_{4}\right)_{6}$ and (b) $\left[\mathrm{Eu}(\mathrm{L}-\alpha \text {-AlahaH })\left(\mathrm{H}_{2} \mathrm{O}\right)_{6}\right]_{2}\left(\mathrm{ClO}_{4}\right)_{8}$ single crystals at $77 \mathrm{~K}$.

Fig. 3. Excitation spectra of (a) $\left[\mathrm{Eu}(\mathrm{DL}-\alpha-\mathrm{Alaha})\left(\mathrm{H}_{2} \mathrm{O}\right)_{6}\right]_{2}\left(\mathrm{ClO}_{4}\right)_{6}$ and (b) $\left[\mathrm{Eu}(\mathrm{L}-\alpha-\mathrm{AlahaH})\left(\mathrm{H}_{2} \mathrm{O}\right)_{6}\right]_{2}\left(\mathrm{ClO}_{4}\right)_{8}$ single crystals at $77 \mathrm{~K}$.
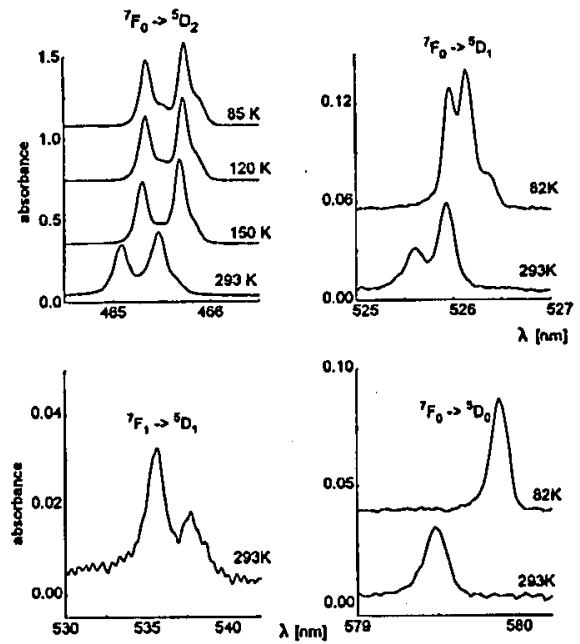

Fig. 4. Absorption spectra of the $\left[\mathrm{Eu}(\mathrm{DL}-\alpha \text {-Alaha })\left(\mathrm{H}_{2} \mathrm{O}\right)_{6}\right]_{2}\left(\mathrm{ClO}_{4}\right)_{6}$ single crystal.

Analysis of the splitting of absorption and emission bands at 82 and $77 \mathrm{~K}$ and considerations based on the group theory enabled us to determine a $C_{2 v}$ symmetry site of metal ion (Figs. 2a, $3 \mathrm{a}$ and 4). Intensity calculations of $f-f$ transition yield relatively high values of oscillator strengths for ${ }^{7} F_{0} \rightarrow{ }^{5} D_{2}$ transition, comparable 


\section{TABLE I}

The oscillator strength values of $f-f$ transitions of the $\left[\mathrm{E} 1(\mathrm{DL}-\alpha-\text { Alaha })\left(\mathrm{H}_{2} \mathrm{O}\right)_{6}\right]_{2}\left(\mathrm{ClO}_{4}\right)_{6}$ single crystal.

\begin{tabular}{c|c|c|c|c|c}
\hline \hline Term & \multicolumn{5}{|c}{$P_{\exp } \times 10^{8}$} \\
\cline { 2 - 6 } & $293 \mathrm{~K}$ & $200 \mathrm{~K}$ & $150 \mathrm{~K}$ & $120 \mathrm{~K}$ & $85 \mathrm{~K}$ \\
\hline${ }^{7} F_{0} \rightarrow{ }^{5} D_{0}$ & 0.471 & 0.471 & - & 0.472 & 0.413 \\
${ }^{7} F_{0} \rightarrow{ }^{5} D_{1}$ & 1.56 & - & - & 2.25 & 2.14 \\
${ }^{7} F_{1} \rightarrow{ }^{5} D_{1}$ & 5.33 & - & - & - & - \\
${ }^{7} F_{0} \rightarrow{ }^{5} D_{2}$ & 15.022 & 15.90 & 15.53 & 15.31 & 16.50 \\
\hline
\end{tabular}

TABLE II

Vibronic components in luminescence and excitation spectra of $\left[\mathrm{Eu}(\mathrm{DL}-\alpha-\mathrm{Alala})\left(\mathrm{II}_{2} \mathrm{O}\right)_{6}\right]_{2}\left(\mathrm{ClO}_{4}\right)_{6}$ single crystal.

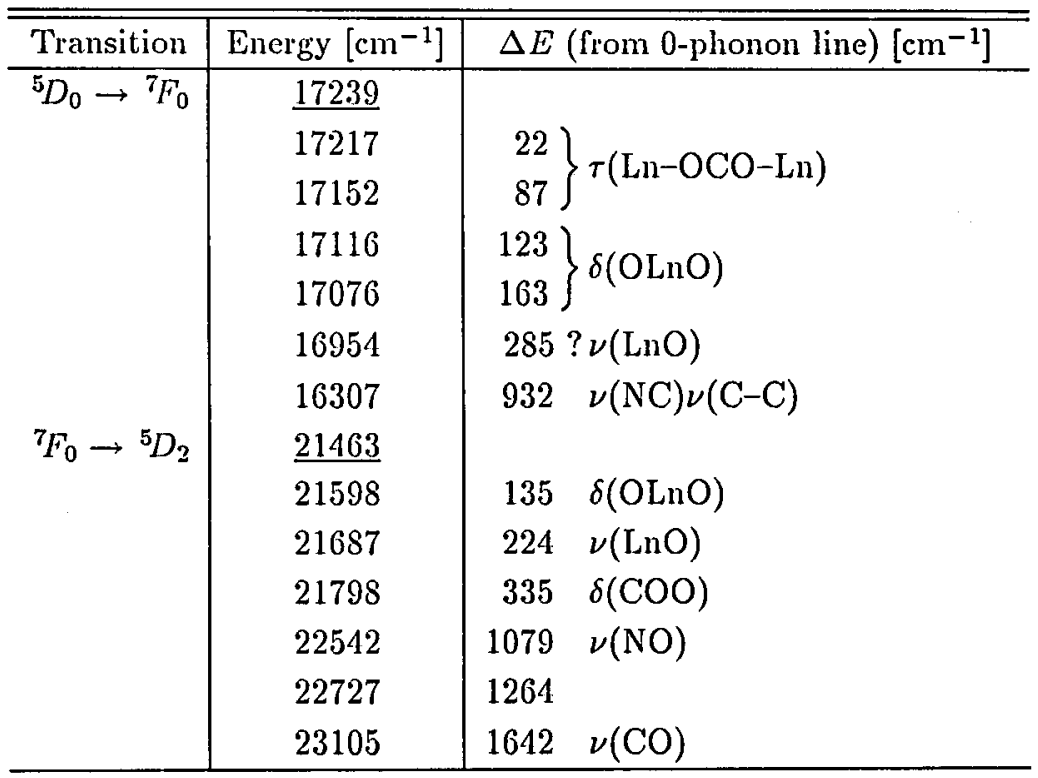

These assignments correspond to our earlier data $[20,28]$ and those to other authors $[29,30]$.

to those reported for $\mathrm{Eu}(\mathrm{NCS})_{3} \cdot 2\left[\mathrm{~N}_{4}\left(\mathrm{CII}_{2}\right)_{6}\right] \cdot 12 \mathrm{II}_{2} \mathrm{O}$ single crystal spectra [21] and europium amide solutions [22], and drastically greater than those reported for $\mathrm{Eu}\left(\mathrm{CCl}_{3} \mathrm{COO}\right)_{3} \cdot 2 \mathrm{II}_{2} \mathrm{O}$ crystals [23] and the $\mathrm{Eu}\left(\mathrm{NO}_{3}\right)_{3} \cdot 2\left[\mathrm{~N}_{4}\left(\mathrm{CH}_{2}\right)_{6}\right] \cdot 10 \mathrm{H}_{2} \mathrm{O}$ ones [24]. Table I compiles the oscillator strength values and their changes with temperature. Note that intensities of ${ }^{7} F_{0} \rightarrow{ }^{5} D_{1}$ and ${ }^{7} F_{0} \rightarrow{ }^{5} D_{2}$ increase with decreasing temperature. This effect clearly shows increasing population of ground ${ }^{7} F_{0}$ level at low temperatures and depopulation of ${ }^{7} F_{1}$ and higher multiplets. 


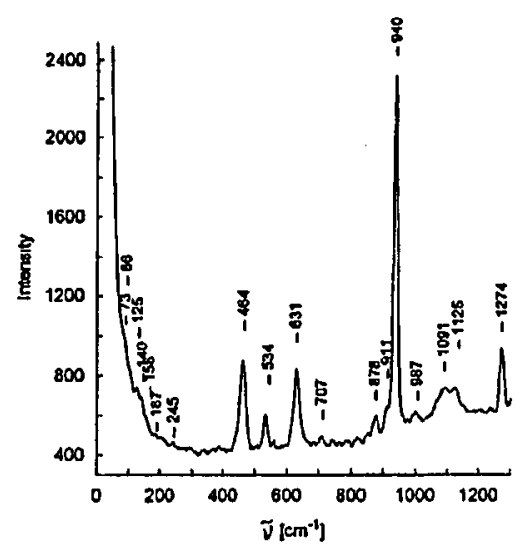

Fig. 5. Raman spectrum of the $\left[\mathrm{Eu}(\mathrm{DL}-\alpha \text {-Alaha })\left(\mathrm{H}_{2} \mathrm{O}\right)_{6}\right]_{2}\left(\mathrm{ClO}_{4}\right)_{6}$ single crystal.

Besides, this process is well seen for excitation spectra in the region of ${ }^{7} F_{0} \rightarrow{ }^{5} D_{1}$ and ${ }^{7} F_{1} \rightarrow{ }^{5} D_{1}$ transitions; the latter one vanishes at $77 \mathrm{~K}$ (Fig. $3 \mathrm{a}$ ).

In fact, for the reason of low probabilities of ${ }^{7} F_{0} \rightarrow{ }^{5} D_{0}$ transitions, almost no effect is seen in their intensities down to $120 \mathrm{~K}$. The decrease in these intensities at $82 \mathrm{~K}$ also could indicate some conformation of the system. Careful analysis of optical lines in the excitation and emission spectra proves that some weak components exist at high energy of ${ }^{7} F_{0} \rightarrow{ }^{5} D_{2}$ transition. These weak components lines could be of vibronic origin, but a cooperative effect of coupled ions cannot be neglected (Table II).

Those weak components in excitation spectra were analysed on the basis of Raman data (Fig. 5). Assignments of vibronic components are collected in Table II. According to the theories of the vibronic transitions probabilities and notation of Blasse and Meijerink [25-27], the vibronic components of $M$ type will accompany electronic transitions which obey the selection rule $D J=0,2$. We detected these weak components in the excitation spectrum of ${ }^{7} F_{0} \rightarrow{ }^{5} D_{2}$ transition, and in the emission one of the ${ }^{5} D_{0} \rightarrow{ }^{7} F_{0}$ band. Inspection of Table II and Figs. 2 and 3 points on the vibronic coupling both with internal and external ligand modes. The strongest vibronic components appear for $\mathrm{C}-\mathrm{O}$ vibration modes $\left(1600 \mathrm{~cm}^{-1}\right)$ or NIIOII and $\mathrm{M}-\mathrm{O}\left(320 \mathrm{~cm}^{-1}\right)$.

\section{Conclusions}

1. Two types of europium with DL- and L-alanine-hydroxamic acids single crystals were obtained. They are, to our knowledge, the first monocrystals with hydroxamic acids derivatives.

2. In the first modification a centrosymmetric dimer is formed, involving $\mathrm{CO}$ and $\mathrm{OH}$ groups of ligand molecules in bonding.

3. In the latter one a noncentrosymmetric system was created; its structure could be solved in two slightly different variations of symmetry, preserving $C 2$ symmetry axes, as well as the lack of the axes. 
There are additional molecules of perchloric acid in cavities of crystal structure. The dynamic hydrogen bonding could exist.

4. Emission spectra detect marked differences in the structure. Investigation of the temperature dependencies of the absorption spectra down to $80 \mathrm{~K}$ enables us to suppose about the internal conformation of the system.

5. Vibronic coupling is strongly manifested with both internal and external ligand modes.

\section{Acknowledgments}

This work was financially supported by the Committee for Scientific Research.

\section{References}

[1] Chemistry and Biology of Fydroxamic Acids, Ed. II. Kehl, Karger, New York 1983.

[2] D.A. Brown, M.V. Chidambaram, in: Metal Ions in Biological Systems, Ed. H. Sigel, Vol. 14, Dekker, New York 1982, p. 125.

[3] J.B. Neilands, Microbial Iron Metabolism, Academic Press, New York 1974.

[4] J.B. Neilands, in: Inorganic Biochemistry, Ed. G. Eichorn, Vol. 1, Elsevier, Amsterdam 1973, Cl. 5.

[5] T. Emery, in: Melal Ions in Biological Systems, Ed. H. Sigel, Vol. 1, Dekker, New York 1978, p. 77.

[6] J.II. Weisburger, E.K. Weisburger, Pharm. Rev. 25, 1 (1973).

[7] II. Maehr, Pure Appl. Chem. 28, 603 (1971).

[8] J. Hase, K. Kobashi, J. Biochem. (Tokyo) 62, 293 (1967).

[9] A.M. Kluchnikova, S.I. Polkin, T.B. Naifonov, Izv. Vyz. Cvet. Metallurgy 3, 59 (1968).

[10] G. Anderegg, F.L. Eplatteneier, G. Schwarzenbach, Helv. Chim. Acta 46, 1409 (1963).

[11] B. Kurzak, J. Jezierska, Inorg. Chim. Acta 153, 193 (1988).

[12] R. Karlicck, M. Polasek, Collect. Czech. Chem. Commun. 53, 592 (1987).

[13] E. Farkas, B. Kurzak, J. Coord. Chem. 22, 145 (1990).

[14] Y.K. Agrawal, P.T. Thomaskutty, Analyst 112, 1015 (1987).

[15] P.T. Thomaskutty, Y.K. Agrawal, J. Radianal. Nucl. Chem. 116, 365 (1987).

[16] Y.K. Agrawal, N. Sinha, S.K. Menon, J. Radianal. Nucl. Chem. 102, 385 (1986).

[17] E. Galdecka, Z. Gałdecki, P. Gawryszewska, J. Legendziewicz, paper in preparation.

[18] B. Kurzak, II. Kozlowski, E. Farkas, Coord. Chem. Rev. 114, 169 (1992), and references cited therein.

[19] B. Kurzak, E. Farkas, T. Głowiak, H. Kozłowski, J. Chem. Soc. Dalton Trans., 163 (1991).

[20] J. Legendziewicz, Z. Ciunik, P. Gawryszewska, J. Sokolnicki, J. Alloys Comp. 225, 372 (1995); T. Glowiak, J. Legendziewicz, E. Huskowska, P. Gawryszewska, Polyhedron, in press; J. Legendziewicz, P. Gawryszewska, Z. Ciunik, J. Sokolnicki, Acta Plys. Pol. A 84, 917 (1993); J. Legendziewicz, in: Excited States of Transition Elements, Eds. B. Jeżowska-Trzebiatowska, J. Legendziewicz, W. Stręk, World Scientific, Singapore 1992, p. 149; U. Kobler, Z. Phys. 247, 289 (1971). 
[21] G. Oczko, M. Zalewicz, J. Legendziewicz, Acta Plıys. Pol. A 90, 431 (1996).

[22] J. Legendziewicz, G. Oczko, W. Stręk, Z. Naturforsch. A 38, 47 (1983).

[23] G. Oczko, J. Legendziewicz, Mat. Chem. Phys. 31, 111 (1992).

[24] G. Oczko, M. Zalewicz, J. Alloys Comp., in press.

[25] A. Meijerink, G. Blasse, J. Sytsma, C. De Mello Donega, A. Ellens, Acta Phys. Pol. A 90, 109 (1996).

[26] G. Blasse, L.H. Brixner, Inorg. Chim. Acta 161, 13 (1990).

[27] G. Blasse, Intern. Rev. Phys. Chem. 11, 71 (1992).

[28] J. Legendziewicz, G. Oczko, W. Stręk, J. Hanuza, Eur. J. Solid Stale Chem., Inorg. Chem. 32, 95 (1995).

[29] D.A. Brown, D. McKeirn, W.K. Glass, Inorg. Chim. Acta 35, 57 (1979).

[30] D.A. Brown, A.L. Roche, Inorg. Chem. 22, 2199 (1983). 